JumalEkonomi Pembangunan Vol. 3, No. 2 (2017) 80-90

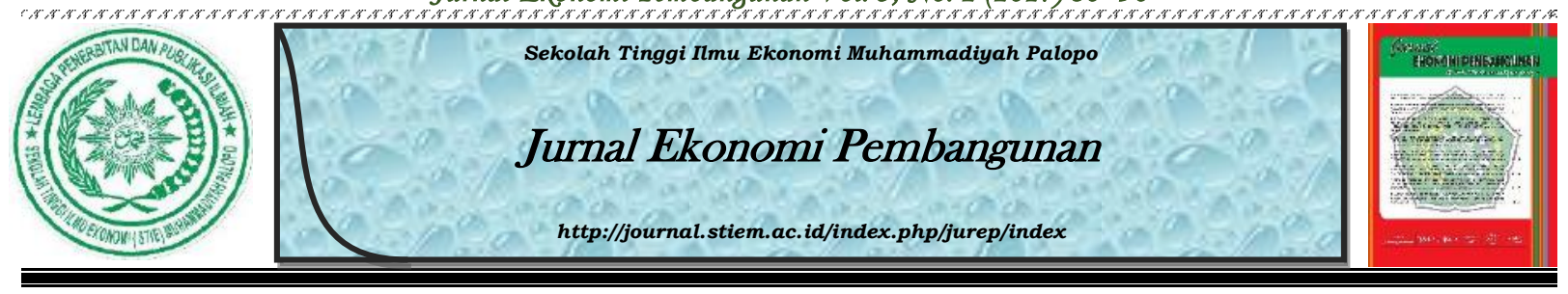

\title{
Penerapan Sistem Akuntansi Keuangan \\ Daerah (SAKD) dan Pengaruhnya terhadap Akuntabilitas Laporan Keuangan Daerah pada Badan Perencanaan Pembangunan Daerah Kota Parepare
}

Arfianty $^{1}$, Asnita Virlayani ${ }^{2}$

$\underline{{ }^{1,2} \text { Universitas Muhammadiyah Parepare }}$

\section{INFO NASKAH

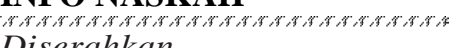 \\ Diserahkan \\ 23 Juli 2017 \\ Diterima \\ 24 Juli 2017 \\ Diterima dalam revisi \\ 14 Desember 2017 \\ Diterima dan disetujui \\ 18 Desember 2017

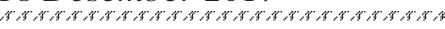

\section{Kata Kunci:}

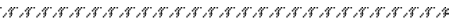

Sistem akuntansi

Keuangan daerah

Akuntabilitas

Laporan keuangan

Laporan keuangan

\begin{abstract}
ABSTRAK

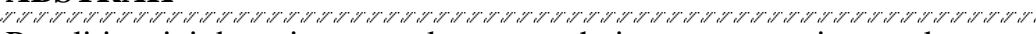
Penelitian ini bertujuan untuk mengetahui penerapan sistem akuntansi keuangan daerah (SAKD) dan pengaruhnya terhadap akuntanbilitas laporan keuangan daerah di Kota Parepare. Populasi dalam penelitian ini adalah pegawai Badan Perencanaan Pembangunan Daerah Kota Parepare sebanyak 45 orang dan sampel yang diambil sebanyak 20 responden. Metode analisis data dalam penelitian ini menggunakan analisis statistik regresi linear. Hasil penelitian menunjukkan bahwa penerapan sistem akuntansi keuangan daerah berpengaruh terhadap akuntabilitas laporan keuangan daerah dinyatakan dengan perhitungan korelasi sebesar 0,87 . Berdasarkan perhitungan koefisien determinasi 75,69\% menunjukkan besarnya pengaruh penerapan sistem akuntansi keuangan daerah terhadap akuntabilitas laporan keuangan. Sedangkan sisanya yaitu sebesar 24,31\% dipengaruhi faktor lain di luar variabel yang diteliti. Hasil penelitian ini memberikan bukti empiris bahwa penerapan sistem akuntansi keuangan daerah memiliki pengaruh terhadap akuntabilitas laporan keuangan daerah. Apabila penerapan sistem akuntansi keuangan daerah diterapkan dengan baik maka akuntabilitas laporan keuangan daerah akan meningkat.
\end{abstract}

\section{Pendahuluan}

Perkembangan akuntansi sektor publik, khususnya di Indonesia semakin pesat dengan adanya era reformasi dalam pelaksanaan kebijakan pemerintah otonomi daerah dan desentralisasi fiskal yang menitikberatkan pada pemerintah daerah. Selain itu, maraknya globalisasi yang menuntut daya saing di setiap negara juga menuntut daya saing di setiap pemerintah daerah. Daya saing pemerintah daerah ini diharapkan akan tercapai melalui peningkatan kemandirian pemerintah daerah yang dapat diraih melalui adanya otonomi 
daerah.

Undang-Undang No. 32 tahun 2004 tentang Pemerintah Daerah dan Undang-Undang No. 33 tahun 2004 tentang Perimbangan Keuangan antara Pemerintah Pusat dan Daerah menjadi landasan yuridis bagi pengembangan otonomi daerah di Indonesia. Otonomi daerah merupakan upaya pemberdayaan daerah dalam pengambilan keputusan daerah secara lebih leluasa untuk mengelola sumber daya yang dimiliki sesuai dengan kepentingan, prioritas, dan potensi daerah sendiri. Adanya otonomi daerah ini memberikan wewenang pengelolaan keuangan sepenuhnya pada pemerintah daerah. Sejalan dengan pelaksanaan otonomi daerah, diperlukan sistem akuntansi yang baik. Sistem akuntansi merupakan pendukung terciptanya pengelolaan keuangan daerah yang akuntabel dalam rangka mengelola dana dengan sistem desentralisasi secara transparan, efisien, efektif, dan dapat dipertanggungjawabkan.

Adapun manfaat penerapan sistem akuntansi keuangan daerah berdasarkan standar akuntansi pemerintahan (PP No. 24 tahun 2004) bertujuan untuk meningkatkan akuntabilitas dan keandalan pengelolaan keuangan pemerintah melalui penyusunan dan pengembangan standar akuntansi pemerintahan. Berdasarkan PP 24 tahun 2005 tentang Standar Akuntansi Pemerintah, pemerintah menyusun sistem akuntansi yang mengacu pada SAP. Sehingga jika penerapan standar akuntansi tidak diterapkan dengan baik maka akan menyebabkan penerapan sistem akuntansi keuangan daerah yang tidak baik juga.

Menurut Mardiasmo (2004:34), untuk dapat menghasilkan laporan keuangan yang relevan, handal, dan dapat dipercaya, pemerintah daerah harus memiliki sistem akuntansi handal. Sistem akuntansi yang lemah menyebabkan laporan keuangan yang dihasilkan juga kurang handal dan kurang relevan untuk pembuatan keputusan. Sehingga penerapan standar akuntansi pemerintah dan penerapan sistem akuntansi keuangan daerah yang tidak baik maka akan menyebabkan kualitas laporan keuangan daerah juga tidak baik.

Aparatur pemerintah daerah yang menangani masalah keuangan tidak cukup hanya menguasai penatausahaan anggaran melainkan juga harus memahami karakteristik transaksi yang terjadi dan pengaruhnya terhadap rekening-rekening dalam laporan keuangan pemerintah daerah. Pemerintah kota Parepare dalam hal ini, masih memiliki masalah dalam SDM khususnya dalam bidang keuangan yang berlatar belakang nonakuntansi. Akibatnya berbagai pelatihan diadakan oleh pemerintah kota Parepare agar mampu meningkatkan kualitas SDM secara maksimal dan penyusunan laporan keuangannya disajikan dengan baik.

Ketersediaan sistem akuntansi keuangan daerah (SAKD) diharapkan meningkatkan 
transparansi dan akuntabilitas dalam pengelolaan keuangan daerah. Sehingga tujuan setiap pemerintah Kabupaten/Kota/Provinsi memiliki kemampuan menyusun laporan keuangan daerah yang mencakup antara lain laporan realisasi anggaran, laporan arus kas, neraca, dan catatan atas laporan keuangan (CALK) dapat tercapai. Penelitian ini bertujuan untuk mengetahui bagaimana penerapan sistem akuntansi keuangan daerah pada Badan Perencanaan Pembangunan Daerah kota Parepare dan pengaruhnya terhadap akuntabilitas laporan keuangan daerah.

\section{Metode Penelitian}

\subsection{Pendekatan Penelitian}

Penelitian ini dilaksanakan di Badan Perencanaan Pembangunan Daerah kota Parepare sedangkan waktu pelaksanaan penelitian berlangsung mulai dari Maret 2017 sampai dengan September 2017. Populasi yang digunakan adalah pegawai Badan Perencanaan Pembangunan Daerah kota Parepare yang berjumlah 45 pegawai. Sedangkan teknik sampling digunakan pada penelitian ini adalah cluster sampling atau sampling area. Peneliti hanya mengambil sampel di beberapa bagian Badan Perencanaan Pembangunan Daerah kota Parepare. Jadi jumlah sampel yang ditentukan peneliti yaitu 20 orang karena keterbatasan dana dan waktu.

\subsection{Variabel Penelitian}

Variabel yang dikaji dalam penelitian ini adalah Sistem Akuntansi Keuangan Daerah dan Akuntabilitas Laporan Keuangan Daerah di Badan Perencanaan Pembangunan Daerah kota Parepare. Semua variabel diukur dengan instrumen pengukur dalam bentuk kuesioner yang memenuhi pernyataan-pernyataan tipe skala likert. Pemberian skor atas pilihan jawaban untuk kuesioner yang diajukan sebagai pernyataan adalah sebagai berikut:

Tabel 1. Skala Likert

\begin{tabular}{|c|l|c|}
\hline No. & \multicolumn{1}{|c|}{ Keterangan } & Skor Positif \\
\hline 1 & Sangat Setuju & 5 \\
\hline 2 & Setuju & 4 \\
\hline 3 & Ragu-ragu & 3 \\
\hline 4 & Tidak Setuju & 2 \\
\hline 5 & Sangat Tidak Setuju & 1 \\
\hline
\end{tabular}

(Sugiyono, 2007) 


\subsection{Analisis Data}

Variabel X (sitem akuntansi keuangan daerah) dan variabel Y (akuntabilitas laporan keuangan daerah) dianalisis dengan perbandingan antara skor aktual dan ideal. Skor aktual diperoleh melalui hasil perhitungan seluruh pendapat responden, sedangakan skor ideal diperoleh dari prediksi nilai tertinggi dikalikan dengan jumlah pertanyaan kuesioner dikalikan dengan jumlah responden. Apabila digambarkan dengan rumus, maka akan tampak seperti di bawah ini:

$\%$ skor aktual $=\frac{\text { skor } \text { aktual }}{\text { skor } \text { ideal }} \times 100 \%$ (1) (Narimawati, 2007)

dimana skor aktual adalah seluruh responden atas kuesioner yang telah diajukan; dan skor ideal adalah skor atau bobot tertinggi atau semua responden diasumsikan memilih jawaban dengan skor tertinggi.

Analisis statistik digunakan dalam penelitian ini untuk mengetahui besarnya pengaruh variabel independen $(\mathrm{X})$ terhadap variabel dependen $(\mathrm{Y})$. Hasil analisis regresi dapat digunakan memutuskan apakah naik dan menurunnya variabel dependen (akuntabilitas laporan keuangan daerah) dapat dilakukan dengan menaikkan dan menurunkan keadaan variabel independen (sistem akuntansi keuangan daerah); atau dengan meningkatkan keadaan variabel dependen (akuntabilitas laporan keuangan daerah) dapat dilakukan dengan meningkatkan variabel independen (sistem akuntansi keuangan daerah). Formula regresi yang digunakan adalah:

$Y=a+b X \ldots \ldots$ (2) $\quad$ (Sugiyono, 2010)

dimana $Y$ adalah nilai yang diprediksikan; $X$ adalah nilai variabel independen; $a$ adalah konstanta; dan $b$ adalah koefisien regresi.

Analisis koefisen korelasi pearson digunakan untuk mengukur ada tidaknya hubungan antara variabel bebas $(\mathrm{X})$ dan variabel terikat $(\mathrm{Y})$ serta mempunyai tujuan untuk meyakinkan bahwa pada kenyataannya terdapat hubungan antara Sistem Akuntansi Keuangan Daerah dengan Akuntabilitas Laporan Keuangan Daerah, dengan formulasi sebagai berikut:

$r=\frac{\mathrm{n} \Sigma X_{i} Y_{i}-\left(\Sigma X_{i}\right)\left(\Sigma Y_{i}\right)}{\sqrt{\left\{n \Sigma X_{i}^{2}-\left(\Sigma X_{i}\right)^{2}\right\}\left\{n \Sigma Y_{i}^{2}-\left(\Sigma Y_{i}\right)^{2}\right\}}} \ldots \ldots \ldots$

dimana $r$ adalah koefisien korelasi; $X$ adalah sistem akuntansi keuangan daerah; $Y$ adalah 
akuntabilitas laporan keuangan daerah; dan $n$ adalah banyaknya sampel.

Besarnya pengaruh variabel $\mathrm{X}$ terhadap variabel Y dapat diketahui dengan menggunakan analisis koefisien determinasi atau disingkat $K d$, yang diperoleh dengan mengkuadratkan koefisien korelasinya. Sehingga koefisien ini berguna untuk mengetahui besarnya kontribusi pengaruh penerapan sistem akuntansi keuangan daerah terhadap akuntabilitas laporan keuangan daerah. Formulasi persamaannya adalah sebagai berikut:

$K d=r^{2} \times 100 \%$

dimana $K d$ nilai koefisien determinasi dan $r^{2}$ adalah koefisien korelasi

\section{Hasil dan Pembahasan}

\subsection{Hasil}

Hasil penelitian diperoleh dari penyebaran angket/kuesioner pada responden sebagai sumber data utama dalam penelitian ini. Selain itu, upaya perolehan data melalui studi pustaka untuk melengkapi data utama. Angket/kuesioner terdiri dari 19 pernyataan dengan perincian 10 pernyataan mengenai sistem akuntansi keuangan daerah dan 9 pernyataan tentang akuntabilitas laporan keuangan daerah. Jumlah responden sebanyak 20 orang dan yang menjadi subyek penelitian adalah bagian-bagian pada Badan Perencanaan Pembangunan Daerah (Bappeda) kota Parepare.

Pengujian validitas digunakan untuk mengukur valid atau invalid suatu pernyataan kuesioner yang disebarkan kepada para responden. Melalui hasil uji validitas dapat dilihat semua instrumen penelitian memilki nilai $r$ hitung lebih besar dari nilai $r$ tabel, artinya semua item pernyataan yang digunakan pada penelitian ini valid. Sedangkan uji reliabilitas merupakan metode untuk mengukur suatu jawaban pernyataan. Suatu kuesioner dikatakan reliabel jika jawaban terhadap pernyataan konsisten. Nilai reliabilitas instrumen penelitian pada masing-masing variabel menunjukkan instrumen yang digunakan untuk mengukur setiap variabel sudah reliabel dengan nilai 0,918 (variabel sistem akuntansi keuangan daerah) dan 0,908 (variabel akuntabilitas laporan keuangan daerah).

\section{Analisis Penerapan Sistem Akuntansi Keuangan Daerah di Bappeda Kota Parepare}

Tanggapan responden mengenai pencatatan yang dilakukan oleh Badan Perencanaan Pembangunan Daerah kota Parepare (Bappeda) menggunakan sistem pencatatan double entry dan cash basis selama tahun anggaran sangat baik. Hal ini tercermin dari persentase skor 
tanggapan responden yaitu 92,33\%, yang termasuk dalam kriteria sangat baik. Tanggapan responden mengenai penggolongan dan pengihktisaran sangat baik. Hal ini dapat dilihat dengan adanya penjurnalan dan melakukan posting ke buku besar sesuai dengan nomor perkiraan yang telah ditetapkan oleh Pemerintah kota Parepare dengan persentase skor tanggapan responden 93,33\% yang masuk dalam kategori sangat baik berdasarkan skor aktual.

Tanggapan responden mengenai pelaporan keuangan Badan Perencanaan Pembangunan Daerah (Bappeda) kota Parepare meliputi laporan realisasi anggaran, laporan arus kas, neraca, dan catatan atas laporan keuangan sangat baik karena penerapan sistem akuntansi keuangan daerah sudah diterapkan secara optimal. Hal ini terlihat dari persentase total skor tanggapan responden $94,5 \%$ termasuk dalam kriteria sangat baik.

Analisis Akuntabilitas Laporan Keuangan Daeah Badan Perencanaan Pembangunan Daerah Kota Parepare

Kuesioner terdiri dari 3 indikator, yaitu integritas keuangan, pengungkapan laporan keuangan, serta ketaatan terhadap peraturan perundang-undangan. Tanggapan responden mengenai integritas keuangan sangat baik dengan jumlah skor 93\% termasuk dalam kategori sangat baik. Tanggapan responden mengenai pengungkapan laporan keuangan dengan konsep full disclosure (pengungkapan penuh) dikatakan sangat baik dengan jumlah skor aktual yaitu 94\% termasuk dalam kategori sangat baik. Tanggapan responden mengenai ketaatan terhadap perundang-undangan dikatakan sangat baik dengan jumlah skor aktual 96,66\% termasuk dalam kategori sangat baik.

Analisis Pengaruh Penerapan Sistem Akuntansi Keuangan Daerah terhadap Akuntabilitas Laporan Keuangan Daerah di Bappeda Kota Parepare

Analisis regresi linier sederhana yang digunakan untuk menguji pengaruh penerapan sistem akuntansi keuangan daerah terhadap akuntabilitas laporan keuangan dengan jumlah $\mathrm{X}=485,56 ; \mathrm{X}^{2}=12382,3 ; \sum X Y=11625,08 ; \mathrm{Y}=459,76$; dan $\mathrm{Y}^{2}=11047,97$ dapat dilihat sebagai berikut:

$\mathrm{a}=\frac{\left(\sum \mathrm{X}^{2}\right)\left(\sum \mathrm{Y}\right)-\left(\sum \mathrm{X}\right)\left(\sum \mathrm{XY}\right)}{\mathrm{n} \sum \mathrm{X}^{2}-\left(\sum \mathrm{X}\right)^{2}}$ 
$\mathrm{a}=\frac{(12.382,30)(459,76)-(485,56)(11.625,08)}{20(12.382,30)-(485,56)^{2}}$

$\mathrm{a}=\frac{5.692 .886,25-5.644 .673,84}{247.646-235.768,51}$

$\mathrm{a}=\frac{48.212,41}{11.877,49} \quad \mathrm{a}=4,059$ dibulatkan menjadi 4,06

$\mathrm{b}=\frac{\mathrm{n} \sum \mathrm{XY}-\left(\sum \mathrm{X}\right)\left(\sum \mathrm{Y}\right)}{\mathrm{n} \sum \mathrm{X}^{2}-\left(\sum \mathrm{X}\right)^{2}}$

$\mathrm{b}=\frac{20(11.625,08)-(485,56)(459,76)}{20(12.382,30)-(485,56)^{2}}$

$\mathrm{b}=\frac{232.501,60-223.241,67}{247.646-235.768,51}$

$\mathrm{b}=\frac{9.260,53}{11.877,49} \quad \mathrm{~b}=0,779$ dibulatkan menjadi 0,78

Berdasarkan hasil penyelesaian di atas, maka didapatkan suatu persamaan regresi sebagai berikut:

$\mathrm{Y}=4,06+0,78 \mathrm{X}$

Analisis korelasi digunakan untuk melihat hubungan antara variabel yang sedang diteliti. Penelitian ini menggunakan dua variabel yang akan dicari hubungannya, yaitu antara variabel $\mathrm{X}$ (sistem akuntansi keuangan daerah) yang diduga memiiki pengaruh dengan akuntabilitas laporan keuangan daerah sebagai variabel Y. Maka Koefisien korelasi adalah sebagai berikut:

$$
\begin{aligned}
& r=\frac{\mathrm{n} \Sigma X_{i} Y_{i}-\left(\Sigma X_{i}\right)\left(\Sigma Y_{i}\right)}{\sqrt{\left\{n \Sigma X_{i}^{2}-\left(\Sigma X_{i}\right)^{2}\right\}\left\{n \Sigma Y_{i}^{2}-\left(\Sigma Y_{i}\right)^{2}\right\}}} \\
& r=\frac{20(11.625,08)-(485,56)(459,76)}{\sqrt{\left\{20(12.382,3)-(485,56)^{2}\right\}\left\{20(11.047,97)-(459,76)^{2}\right\}}}
\end{aligned}
$$


$r=\frac{232.501,60-223.241,07}{\sqrt{\{11.877,49\}\{9.579,54\}}}$

$r=\frac{9.260,53}{\sqrt{113.788 .017,05}} \quad r=\frac{9.260,53}{10.667,147} \quad r=0,868$ dibulatkan menjadi 0,87

Berdasarkan hasil pengolahan tersebut, dapat dilihat bahwa koefisien hubungan antara variabel sistem akuntansi keuangan daerah dengan akuntabilitas laporan keuangan daerah adalah sebesar 0,87 . Hal ini menunjukkan terdapat hubungan yang sangat kuat antara sistem akuntansi keuangan daerah dengan akuntabilitas laporan keuangan daerah pada Badan Perencanaan Pembangunan Daerah kota Parepare. Hubungan yang baik ditunjukkan dengan hasil positif yang menunjukkan bahwa semakin baik penerapan sistem akuntansi keuangan daerah membuat akuntabilitas laporan keuangan daerah semakin tinggi. Demikian pula sebaliknya, semakin buruk penerapan sistem akuntansi keuangan daerah akan membuat akuntabilitas laporan keuangan daerah semakin rendah.

Koefisien determinasi ( $r$-square) merupakan koefisien yang digunakan untuk mengetahui besarnya kontribusi variabel independen terhadap perubahan variabel dependen. Hasil perhitungan koefisien determinasi yang dilakukan menggunakan rumus sebagai berikut:

$K d=0,87^{2} \times 100 \%$

$K d=0,7569 \times 100 \%$

$K d=75,69 \%$

Hasil perhitungan tersebut menunjukkan bahwa sistem akuntansi keuangan daerah (X) berpengaruh terhadap akuntabilitas laporan keuangan daerah (Y) dengan besarnya pengaruh sebesar 75,69\%. Berarti akuntabilitas laporan keuangan daerah sebesar 75,69\% dipengaruhi oleh sistem akuntansi keuangan daerah, dan sisanya 24,31\% dipengaruhi oleh faktor lain yang tidak diteliti penulis, seperti mentalitas pejabat berwenang sebagai bagian dari dimensi akuntabilitas hukum dan kejujuran, prosedur yang ditetapkan oleh pihak manajerial sebagai bagian dari dimensi akuntabilitas manajerial, tujuan awal dari sistem itu sendiri sebagai bagian dari dimensi akuntabilitas program, pertanggungjawaban kualitas laporan keuangan sebagai bagian dari akuntabilitas finansial, serta kebijakan lainnya yang diambil Pemerintah selain kebijakan sistem itu sendiri. 


\subsection{Pembahasan}

Hasil pengujian menunjukkan bahwa pengaruh penerapan sistem akuntansi keuangan daerah terhadap akuntabilitas laporan keuangan daerah dinyatakan dengan perhitungan korelasi sebesar 0,87 . Hal ini mengindikasikan terdapat hubungan yang sangat kuat antara sistem akuntansi keuangan daerah dengan akuntabilitas laporan keuangan daerah di Bappeda kota Parepare. Arah hubungan yang positif menunjukkan bahwa semakin baik penerapan sistem akuntansi keuangan daerah terhadap akuntabilitas laporan keuangan daerah di Bappeda kota Parepare. Berdasarkan perhitungan koefisien determinasi dengan nilai sebesar 75,69\% menunjukkan besarnya pengaruh penerapan sistem akuntansi keuangan daerah terhadap akuntabilitas laporan keuangan daerah di Badan Perencanaan Pembangunan Daerah kota Parepare. Sedangkan sisanya yaitu sebesar $24,31 \%$ dipengaruhi faktor lain di luar variabel yang diteliti.

Hasil penelitian ini memberikan bukti empiris bahwa penerapan sistem akuntansi keuangan daerah memiliki pengaruh terhadap akuntabilitas laporan keuangan daerah. Artinya apabila penerapan sistem akuntansi keuangan daerah diterapkan dengan baik, maka akuntabilitas laporan keuangan daerah akan meningkat. Hal tersebut membuktikan teori yang dikemukakan oleh Mardiasmo (2002:176) sebagai berikut:

"Akuntansi keuangan daerah memiliki peran utama untuk menyiapkan laporan keuangan sebagai salah satu bentuk pelaksanaan akuntabilitas publik."

Hasil pengujian dalam penelitian ini menunjukkan bahwa sistem akuntansi keuangan daerah Bappeda kota Parepare telah berjalan dengan baik sehingga akuntabilitas laporan keuangan daerah juga dapat berjalan dengan baik sesuai dengan teori yang dikemukakan oleh Mardiasmo (2002).

\section{Kesimpulan dan Saran}

Penerapan sistem akuntansi keuangan daerah pada Badan Perencanaan pembangunan Daerah kota Parepare menunjukkan kriteria sangat baik. Hal ini dikarenakan proses pencatatan yang dilakukan sepenuhnya menggunakan sistem pencatatan berpasangan (double entry); basis kas; dan basis akrual. Sehingga informasi yang akan diberikan kepada publik andal dan jelas. Akuntabilitas laporan keuangan daerah di Badan Perencanaan Pembangunan Daerah kota Parepare sudah termasuk dalam kategori sangat baik. Artinya ditinjau dari integritas keuangan, pengungkapan laporan keuangan, dan ketaatan terhadap perundang- 
undangan sudah dilakukan dengan baik dan dapat dipertanggungjawabkan kepada publik.

Sistem akuntansi keuangan daerah berpengaruh terhadap akuntabilitas laporan keuangan daerah pada Badan Perencanaan Pembangunan Daerah kota Parepare. Artinya semakin baik penerapan sistem akuntansi keuangan daerah akan membuat akuntabilitas laporan keuangan daerah semakin tinggi. Demikian pula sebaliknya, semakin buruk penerapan Sistem akuntansi keuangan daerah akan membuat akuntabilitas laporan keuangan daerah semakin rendah.

Hasil penelitian ini memiliki beberapa keterbatasan. Pertama, peneliain ini fokus pada variabel sistem akuntansi keuangan daerah sebagai variabel yang mempengaruhi akuntabilitas. Oleh karena itu, untuk penelitian selanjutnya sebaiknya menggunakan proksi lain yang dianggap dapat berpengaruh terhadap akuntabilitas laporan keuangan. Kedua, penelitian ini tidak dapat digeneralisasi dengan hasil penelitian lainnya karena dilakukan pada satu wilayah kota saja. Sebaiknya penelitian selanjutnya lebih memperluas cakupan penelitian tidak hanya pada satu dinas saja atau melakukan pengembangan dengan perbandingan institusi.

\section{Daftar Pustaka}

Afifah, N.N. 2009 Akuntansi Pemerintahan: Implementasi Akuntansi Keuangan Pemerintah Dearah. Jakarta: Kencana.

Halim, A. 2004. Akuntansi Sektor Publik: Akuntansi Keuangan Daerah. Jakarta: Salemba Empat.

Kadir, A. 2003. Pengenalan Sistem Akuntansi. Yogyakarta: Andi.

Latifah, L. dan A. Sabeni. 2007. Faktor Keprilakuan Organisasi dalam Implementasi Sistem Akuntansi Keuangan Daerah (Studi Empiris Pada Pemerintah Kabupaten dan Kota di Jawa Tengah dan Daerah Istimewa Yogyakarta). Simposium Nasional Akuntansi 10. Makassar.

Mardiasmo. 2002. Akuntansi Sektor Publik. Yogyakarta: Andi.

Mardiasmo. 2004. Otonom dan Manajemen Keuangan Daerah. Yogyakarta: Andi.

Mauliyah, D. 2008. Penerapan Sistem Akuntansi Keuangan Daerah dalam Mewujudkan Transparansi dan Akuntabilitas Pendapatan Pajak Daerah.

Mulyadi. 2001. Sistem Akuntansi. Edisi Ketiga. Jakarta: Salemba Empat.

Narimawati, U. 2007. Riset Manajemen Sumber Daya Manusia. Jakarta: Agung Media.

Republik Indonesia. Peraturan Pemerintah Nomor 56 Tahun 2005 tentang Sistem Informasi Keuangan Daerah. 
Republik Indonesia. Peraturan Pemerintah Nomor 58 Tahun 2005 tentang Pengelolahan Keuangan Daerah.

Republik Indonesia. Peraturan Pemerintah Nomor 24 Tahun 2005 tentang Standar Akuntansi Pemerintah.

Republik Indonesia. Permendegri Nomor 13 Tahun 2006 tentang Pengelolaan Dan Pertanggungjawaban Keuangan Daerah.

Republik Indonesia. Undang-Undang Nomor 32 tahun 2004 tentang Pemerintahan Daerah. Republik Indonesia.

Republik Indonesia. Undang-Undang Nomor 33 tahun 2004 tentang Perimbangan Keuangan Pemerintah Pusat dan Daerah.

Rudianto. 2009. Pengantar Akuntansi. Jakarta: Erlangga.

Saifuddin, A. 1998. Metode Penelitian. Yogyakarta: Pustaka Pelajar.

Sugiyono. 2007. Metode Penelitian Bisnis. Bandung: Alfabeta.

Sugiyono. 2010. Metode Penelitian Pendidikan (Pendekatan kuantitatif, Kualitatif, dan R dan $D)$. Bandung: Alfabeta.

Sunyoto. 2000. Metodologi Penelitian Ekonomi. Yogyakarta: Caps Publising.

Susanto, A. 2004. Sistem Akuntansi dan Konsep Pengembangan Berbasis Komputer. Bandung: Lingga Jaya.

Ulum, I. 2004. Sebuah Pengantar Akuntansi Sektor Publik. Malang: UMM Press. 